\title{
Pengaruh Penerapan Model Pembelajaran Project Based Learning (PJBL) Terhadap Hasil Belajar Kognitif Siswa Pada Mata Pelajaran IPA di Kelas V SD Negeri 5 Kota Bengkulu
}

\author{
Wiki Apriany \\ Program Magister Pendidikan Dasar Universitas Bengkulu. \\ aprianywiki@gmail.com \\ Endang Widi Winarni \\ Program Magister Pendidikan Dasar Universitas Bengkulu.
}

Abdul Muktadir

Program Magister Pendidikan Dasar Universitas Bengkulu.

\begin{abstract}
Tujuan penelitian ini untuk mengetahui kualitas projek yang dihasilkan siswa setelah penerapan model pembelajaran PjBL pada mata pelajaran IPA kelas V SDN 5 Kota Bengkulu dan untuk mengetahui pengaruh model pembelajaran PjBL terhadap hasil belajar kognitif siswa yang terdiri dari level pemahaman, penerapan, dan penalaran. Jenis penelitan yang digunakan dalam penelitian ini eksperimen semu dengan desain "The matching only pretestposttest control group design". Sampel penelitian terdiri dari 76 siswa SDN 05 sebagai kelas eksperimen dan SDN 20 sebagai kelas control. Instrument penelitian ini yaitu lembar penilaian kualitas proyek dan soal tes. Data hasil penelitian menunjukkan bahwa; (1) Kualitas projek yang dihasilkan siswa setelah penerapan model pembelajaran PjBL adalah baik. Berdasarkan indikator tampilan secara keseluruhan, komposisi bagian-bagian dari ekosistem, projek yang dihasilkan mempunyai estetika tinggi (perpaduan warna, keserasian dalam penempatan objek, kerapian produk), dan kualitas detail tiap-tiap bagian diorama; (2) Terdapat pengaruh model pembelajaran PjBL terhadap hasil belajar kognitif siswa level pemahaman dengan hasil t hitung=3,020 $>\mathrm{t}$ tabel 1,66; (3) Terdapat pengaruh model pembelajaran PjBL terhadap hasil belajar kognitif siswa level penerapan dengan hasil t hitung=5,667 > t tabel 1,66; dan (4) Terdapat pengaruh model pembelajaran $\mathrm{PjBL}$ terhadap hasil belajar kognitif siswa level penalaran dengan hasil t hitung=0,61 $<\mathrm{t}$ tabel 1,66. Berdasarkan data di atas, dapat disimpulkan bahwa secara keseluruhan terdapat pengaruh model pembelajaran PjBL terhadap hasil belajar kognitif siswa pada mata pelajaran IPA.
\end{abstract}

Kata Kunci: Model Pembelajaran PjBL, Hasil Belajar Kognitif 


\section{Pendahuluan}

Pembelajaran IPA pada hakikatnya adalah scientific inquiry, yaitu pemberian pengalaman belajar secara langsung melalui penggunaan dan pengembangan ketrampilan proses dan sikap ilmiah. Sehingga di dalam pembelajaran IPA di SD diperlukan model pembelajaran inovatif, sehingga siswa mengalami atau berbuat dan menemukan pengetahuannya sendiri dengan bimbingan dari guru. Model pembelajaran yang inovatif dan variatif diperlukan untuk menunjang ketercapaian dari tujuan pembelajaran IPA yang diharapkan. Karena pemilihan model pembelajaran yang tepat akan mampu menarik perhatian siswa untuk ikut aktif mengikuti proses pembelajaran. Siswa yang aktif mengikuti proses pembelajaran akan berusaha mengembangkan segala potensi yang dimilikinya guna mencapai tujuan pembelajaran yang diharapkan.

Salah satu model pembelajaran yang bersifat scientific inquiry yaitu Project Based Learning. Project Based Learning ialah proses pembelajaran yang secara langsung melibatkan siswa untuk menghasilkan suatu proyek. Pada dasarnya model pembelajaran ini lebih mengembangkan keterampilan memecahkan masalah dalam mengerjakan sebuah proyek yang dapat menghasilkan sesuatu. Seperti yang dikemukakan oleh Thomas (dalam Farid dan Pramukantoro 2013: 739) Fokus pembelajaran terletak pada konsep dan prinsip inti dari suatu disiplin studi, melibatkan siswa dalam investigasi pemecahan masalah dan kegiatan tugas-tugas bermakna yang lain, memberi kesempatan siswa bekerja secara otonom mengkonstruk pengetahuan mereka sendiri, dan mencapai puncaknya menghasilkan produk nyata.

Keunggulan yang dimiliki pada model pembelajaran berbasis proyek yaitu mampu meningkatkan motivasi siswa, kemampuan pemecahan masalah dan sikap kerjasama, dan keterampilan mengelola sumber. Proses pembelajaran berbasis proyek dapat membuat siswa lebih mudah memahami materi, karena siswa langsung menerapkan ilmunya ke dalam sebuah proyek yang mereka susun. Proyek tersebut akan membuat siswa lebih mudah mengingat konsep yang telah diperoleh. $\mathrm{PjBl}$ merupakan salah satu alternatif pembelajaran yang bisa digunakan tidak hanya untuk menilai aspek kognitif, tetapi juga unjuk kerja siswa (Hayati et al., 2013).

Hasil penelitian terdahulu yang relevan menunjukkan bahwa $\mathrm{PjBl}$ mampu meningkatkan kemampuan berfikir kognitif siswa, khususnya pada pembelajaran IPA di tingkat sekolah dasar. Seperti hasil penelitian oleh Nugraha et al (2018) yang 
bertujuan untuk meningkat kreativitas dan hasil belajar IPA melalui model pembelajaran Project Based Learning. Jadi, dengan menerapkan model pembelajaran Project Based Learning ( $\mathrm{PjBl}$ ) dapat meningkatkan kreativitas dan hasil belajar IPA siswa kelas 5 SD. Selanjutnya, penelitian oleh Mustikaningrum (2015) yang bertujuan untuk mengetahui hubungan pembelajaran PjBL berbantuan fotonovela dengan hasil belajar siswa dan hubungan pembelajaran PjBL berbantuan fotonovela dengan sikapsains siswa.Hasil dari penelitian ini terdapat hubungan antara model pembelajaran PjBL berbantuan fotonovela dengan hasil belajar siswa.

Berdasarkan hasil pengambilan data awal, peneliti menemukan bahwa siswa kelas V SDN 5 Kota Bengkulu mengalami beberapa kendala dalam mencapai nilai ambang batas yang sudah ditentukan oleh pihak sekolah, khususnya pada mata pelajaran IPA. Beberapa kendala yang dihadapi yaitu; (1) siswa sulit menjawab soal yang diberikan sehingga mempengaruhi ketuntasan hasil belajar kognitif siswa pada mata pelajaran IPA; (2) kurangnya motivasi siswa dalam belajar IPA; (3) siswa cenderung lebih pasif di dalam kelas; (4) kurangnya kreativitas siswa dalam belajar IPA; dan (5) guru sering menggunakan model pembelajaran konvensional dan monoton sehingga sangat jarang menggunakan model pembelajaran berkelompok dalam pemecahan masalah.

Berlandaskan permasalahan yang ditemukan tersebut, peneliti ingin menerapkan model pembelajaran Project Based Learning $(\mathrm{PjBl})$ guna meningkatkan hasil belajar kognitif siswa dalam mata pelajaran IPA. Langkah-langkah pembelajaran dalam model pembelajaran Project Based Learning sebagaimana yang dikembangkan oleh The George Lucas Educational Foundation (dalam Wahyu 2017:57) terdiri dari : 1) Start With the Essential Question, dimana pembelajaran dimulai dengan pertanyaan esensial. 2) Design a Plan for the Project, melakukan perencanaan secara kolaboratif antara pengajar dan peserta didik agar siswa merasa "memiliki" atas proyek tersebut. 3) Create a Schedule, menyusun jadwal aktivitas dalam menyelesaikan proyek. 4) Monitor the Students and the Progress of the Project, memonitor aktivitas peserta didik selama menyelesaikan proyek. 5) Assess the Outcome, memberikan penilaian untuk membantu pengajar dalam menyusun strategi pembelajaran berikutnya. 6) Evaluate the Experience, pengajar dan peserta didik melakukan refleksi terhadap aktivitas dan hasil proyek yang sudah dijalankan dengan mengungkapkan perasaan dan pengalaman siswa selama menyelesaikan proyek.

Penerapan model $\mathrm{PjBl}$ berbantu diorama ini diharapkan juga dapat membantu siswa dalam mencapai beberapa tujuan pendidikan IPA di sekolah dasar yaitu untuk mengembangkan pengetahuan dan pemahaman konsep-konsep IPA 
Pengaruh Penerapan Model Pembelajaran Project Based Learning (PJBL) terhadap

Hasil Belajar Kognitif Siswa pada Mata Pelajaran IPA di Kelas V SD Negeri 5

Kota Bengkulu

yang bermanfaat dan dapat diterapkan dalam kehidupan sehari-hari dan mengembangkan rasa ingin tahu, sikap positif dan kesadaran tentang adanya hubungan yang saling mempengaruhi antara IPA, lingkungan, dan masyarakat. Sehingga peneliti akan melakukan penelitian berjudul "Pengaruh penerapan model pembelajaran Project Based Learning (PjBl) Terhadap Hasil Belajar Kognitif Siswa Pada Mata Pelajaran IPA Di Kelas V SDN 05 Kota Begkulu".

\section{Metode}

Jenis penelitan yang digunakan dalam penelitian ini eksperimen semu. Eksperimen semu yaitu eksperimen yang dilaksanakan pada dua kelompok sampel yaitu kelompok eksperimen dan kelompok kontrol. Desain penelitian ini yaitu eksperimen semu menggunakan desain "The matching only pretest-posttest control group design" karena bertujuan untuk mencari pengaruh. Penelitian ini dilaksanakan di SDN 5 sebagai kelas eksperimen yang bertempat di Jalan Cimanuk dan SDN 20 sebagai kelas kontrol yang beralamat di KM8, kota Bengkulu dengan jumlah total sampel penelitian yaitu 76 siswa. Teknik pengumpulan data dalam penelitian ini menggunakan tes pemberian soal tentang materi ekosistem pada pembelajaran IPA yang disusun oleh peneliti yang telah divalidasi dan lembar penilaian kualitas proyek Teknik pengumpulan data menggunakan teknik tes pilihan ganda yang terdiri dari pretest dan postest.

\section{Hasil dan Pembahasan}

Penelitian ini bertujuan untuk mengetahui kualitas projek yang dihasilkan siswa yaitu Kualitas projek yang dihasilkan siswa setelah penerapan model pembelajaran PjBL adalah baik. Berdasarkan indikator tampilan secara keseluruhan, komposisi bagian-bagian dari ekosistem, projek yang dihasilkan mempunyai estetika tinggi (perpaduan warna, keserasian dalam penempatan objek, kerapian produk), dan kualitas detail tiaptiap bagian diorama serta mengukur ranah kognitif yang terbagi dalam 3 level yaitu level pemahaman (C1,C2), penerapan (C3), dan penalaran $(\mathrm{C} 4, \mathrm{C} 5, \mathrm{C} 6)$. Terdapat 10 butir soal yang termasuk pada level pemahaman, 10 butir soal pada level penerapan, dan 10 butir soal pada level penalaran. Kemampuan ranah kognitif hasil belajar IPA dilihat dari kenaikan nilai siswa pada hasil pretest dan posttest yang diberikan peneliti kepada kedua kelas, baik eksperimen maupun kontrol. Selain kenaikan tersebut, peneliti juga menganalisis dengan menggunakan uji-t untuk menarik kesimpulan ada atau tidaknya model pembelajaran PjBL terhadap variabel penelitian ini. Berikut rekap ranah kognitif hasil belajar IPA siswa kelas eksperimen dan kontrol. 
Tabel 1 Rekap Hasil Belajar IPA siswa Kelas Kontrol dan Eksperimen

\begin{tabular}{|l|l|l|l|l|}
\hline \multirow{2}{*}{$\begin{array}{l}\text { Deskr } \\
\text { ipsi }\end{array}$} & $\begin{array}{l}|c| \\
\text { Pretest } \\
\text { men }\end{array}$ & $\begin{array}{l}\text { Kont } \\
\text { rol }\end{array}$ & $\begin{array}{l}\text { Eksperi } \\
\text { men }\end{array}$ & $\begin{array}{l}\text { Kont } \\
\text { rol }\end{array}$ \\
\hline $\begin{array}{l}\text { Nilai } \\
\text { Tertin } \\
\text { ggi }\end{array}$ & 83 & 83 & 93 & 93 \\
\hline $\begin{array}{l}\text { Nilai } \\
\text { Teren } \\
\text { dah }\end{array}$ & 50 & 50 & 50 & 43 \\
\hline $\begin{array}{l}\text { Rata- } \\
\text { Rata }\end{array}$ & 65,28 & 64,8 & 80,34 & 66,8 \\
\hline $\begin{array}{l}\text { Varia } \\
\text { n }\end{array}$ & 96,13 & 68,1 & 95,79 & 165, \\
\hline $\begin{array}{l}\text { Stand } \\
\text { ar }\end{array}$ & 9,81 & 8,25 & 9,78 & 12,8 \\
$\begin{array}{l}\text { Devia } \\
\text { si }\end{array}$ & & 9 & & 5 \\
\hline
\end{tabular}

Berdasarkan Tabel 1 menunjukkan bahwa nilai rata-rata kelas eksperimen pada pretest dan posttest lebih besar daripada kelas kontrol. Rata-rata nilai kelas eksperimen pada pretest yaitu 65,28 sedangkan kelas kontrol 64,84. Selanjutnya rata-rata nilai posttest eksperimen lebih tinggi dibanding kelas kontrol yaitu 80,34 pada kelas eksperimen dan 66,84 pada kelas kontrol. Nilai varian pada posttest kelas kontrol lebih tinggi yakni 165,27 yang mana varian pada kelas eksperimen hanya 95,79. Begitupun dengan standar deviasi kelas kontrol lebih tinggi dari pada kelas eksperimen.

Selanjutnya uji hipotesis juga dilakukan berdasarkan tiga level kognitif siswa pada hasil posttest setelah menerapkan model pembelajaran PjBL, yaitu: level pemahaman, penerapan, dan penalaran.

\section{a. Level Pemahaman}

Pada level pemahaman ini, peneliti menguji hipotesis mengenai pengaruh penerapan model pembelajaran PjBL terhadap kemampuan kognitif siswa level pemahaman. Sebelum peneliti melakukan uji hipotesis pada masing-masing level, peneliti mengelompokkan jawaban siswa sesuai dengan masing-masing level kognitif.

Hipotesis yang diajukan yaitu:

a. $\mathrm{HO}=$ Tidak terdapat pengaruh yang signifikan model pembelajaran project based learning $(\mathrm{PjBl})$ terhadap hasil belajar kognitif level pemahaman pada pembelajaran IPA.

b. $\mathrm{Ha}=$ Terdapat pengaruh yang signifikan model pembelajaran project based learning $(\mathrm{PjBl})$ terhadap hasil belajar kognitif level pemahaman pada pembelajaran IPA. 
Pengaruh Penerapan Model Pembelajaran Project Based Learning (PJBL) terhadap

Hasil Belajar Kognitif Siswa pada Mata Pelajaran IPA di Kelas V SD Negeri 5

Kota Bengkulu

Untuk menguji hipotesis di atas, maka peneliti menggunakan data hasil Pretest dan posttest hasil belajar IPA ranah kognitif level pemahaman untuk digunakan sebagai penarikan kesimpulan atas pelaksanaan penelitian ini. Adapun hasil uji hipotesis pada data pretest dan posttest sebagai berikut:

\section{Tabel 2 Hasil Uji Hipotesis Pretest Level Pemahaman}

\begin{tabular}{|c|c|c|}
\hline Data & $\begin{array}{c}\text { Kelas } \\
\text { Experimen }\end{array}$ & $\begin{array}{c}\text { Kelas } \\
\text { Kontrol }\end{array}$ \\
\hline Rata-Rata & 6,67 & 6,71 \\
\hline $\mathrm{N}$ & 38 & 38 \\
\hline Df & \multicolumn{2}{|c|}{74} \\
\hline$t_{\text {hitung }}$ & \multicolumn{2}{|c|}{0,451} \\
\hline$t_{\text {tabel }}$ & \multicolumn{2}{|c|}{1,66} \\
\hline Kesimpulan & \multicolumn{2}{|c|}{$\begin{aligned} t_{\text {hitung }} & <t_{\text {tabel }} \text { maka } \mathrm{H}_{0} \\
& \text { diterima }\end{aligned}$} \\
\hline
\end{tabular}

Berdasarkan Tabel 2 menunjukkan bahwa rata-rata nilai pada kelas eksperimen level pemahaman sebesar 6,67 dan kelas kontrol sebesar 6,71. Data tersebut menunjukkan bahwa rata-rata kelas eksperimen lebih kecil dari pada kelas kontrol. Kemudian, didapat thitung $=0,451<$ ttabel=1,66. Sehingga dapat disimpulkan bahwa H0 yang menyatakan tidak terdapat pengaruh yang signifikan model pembelajaran project based learning $(\mathrm{PjBl})$ terhadap hasil belajar kognitif level pemahaman pada pembelajaran IPA diterima.

Tabel 3 Hasil Uji Hipotesis Posttest Level Pemahaman

\begin{tabular}{|l|c|c|}
\hline \multicolumn{1}{|c|}{ Data } & $\begin{array}{c}\text { Kelas } \\
\text { Experimen }\end{array}$ & $\begin{array}{c}\text { Kelas } \\
\text { Kontrol }\end{array}$ \\
\hline Rata-Rata & 8,71 & 7,78 \\
\hline $\mathrm{N}$ & 38 & 38 \\
\hline $\mathrm{Df}$ & \multicolumn{2}{|c|}{74} \\
\hline $\mathrm{t}_{\text {hitung }}$ & \multicolumn{2}{|c|}{3,205} \\
\hline $\mathrm{t}_{\text {tabel }}$ & \multicolumn{2}{|c|}{1,66} \\
\hline Kesimpulan & $\mathrm{t}_{\text {hitung }}>\mathrm{t}_{\text {tabel }}$ maka $\mathrm{H}_{0}$ \\
ditolak
\end{tabular}

Berdasarkan Tabel 3 menunjukkan bahwa rata-rata nilai pada kelas eksperimen level pemahaman sebesar 8,71 dan kelas kontrol sebesar 7,78. Data tersebut menunjukkan bahwa rata-rata kelas eksperimen lebih besar dari pada kelas kontrol. Kemudian, didapat thitung=3,205 $>$ ttabel=1,66. Sehingga dapat disimpulkan bahwa $\mathrm{H} 0$ yang menyatakan tidak terdapat pengaruh yang signifikan model $\mathrm{PjBL}$ terhadap hasil belajar kognitif level pemahaman pada pembelajaran IPA ditolak.

\section{b. Level Penerapan}

Pada level penerapan ini, peneliti menguji hipotesis mengenai pengaruh penerapan model pembelajaran PjBL terhadap kemampuan kognitif siswa level penerapan. 
Sebelum peneliti melakukan uji hipotesis pada masing-masing level, peneliti mengelompokkan jawaban siswa sesuai dengan masing-masing level kognitif. Untuk menguji hipotesis tersebut, maka peneliti menggunakan data hasil Pretest dan posttest hasil belajar IPA ranah kognitif level penerapan sebagai penarikan kesimpulan atas pelaksanaan penelitian ini. Adapun hasil uji hipotesis pada data pretest dan posttest sebagai berikut:

\section{Tabel 4 Hasil Uji Hipotesis Pretest Level Penerapan}

\begin{tabular}{|l|c|c|}
\hline \multicolumn{1}{|c|}{ Data } & $\begin{array}{c}\text { Kelas } \\
\text { Experimen }\end{array}$ & $\begin{array}{c}\text { Kelas } \\
\text { Kontrol }\end{array}$ \\
\hline Rata-Rata & 5,28 & 5,30 \\
\hline $\mathrm{N}$ & 38 & 38 \\
\hline $\mathrm{Df}$ & \multicolumn{2}{|c|}{74} \\
\hline $\mathrm{t}_{\text {hitung }}$ & \multicolumn{2}{|c|}{0,872} \\
\hline $\mathrm{tt}_{\text {abel }}$ & \multicolumn{2}{|c|}{1,66} \\
\hline Kesimpulan & $\begin{array}{c}\mathrm{t}_{\text {hitung }}<\mathrm{t}_{\text {tabel }} \text { maka } \mathrm{H}_{0} \\
\text { diterima }\end{array}$ \\
\hline
\end{tabular}

Berdasarkan Tabel 4 menunjukkan bahwa rata-rata nilai pada kelas eksperimen level penerapan sebesar 5,28 dan kelas kontrol sebesar 5,30. Data tersebut menunjukkan bahwa rata-rata kelas eksperimen lebih kecil dari pada kelas kontrol. Kemudian, didapat thitung=0,872< ttabel=1,66 sehingga dapat disimpulkan bahwa H0 yang menyatakan tidak terdapat pengaruh yang signifikan model pembelajaran project based learning $(\mathrm{PjBl})$ terhadap hasil belajar kognitif level peerapan pada pembelajaran IPA diterima.

Tabel 5 Hasil Uji Hipotesis Posttest Level Penerapan

\begin{tabular}{|l|c|c|}
\hline \multicolumn{1}{|c|}{ Data } & $\begin{array}{c}\text { Kelas } \\
\text { Experimen }\end{array}$ & $\begin{array}{c}\text { Kelas } \\
\text { Kontrol }\end{array}$ \\
\hline Rata-Rata & 7,28 & 5,60 \\
\hline $\mathrm{N}$ & 38 & 38 \\
\hline $\mathrm{Df}$ & \multicolumn{2}{|c|}{74} \\
\hline $\mathrm{t}_{\text {hitung }}$ & \multicolumn{2}{|c|}{4,434} \\
\hline $\mathrm{tt}_{\text {abel }}$ & \multicolumn{2}{|c|}{1,66} \\
\hline Kesimpulan & $\mathrm{t}_{\text {hitung }}>\mathrm{t}_{\text {tabel }}$ maka $\mathrm{H}_{0}$ \\
ditolak
\end{tabular}

Berdasarkan Tabel 5 menunjukkan bahwa rata-rata nilai pada kelas eksperimen level penerapan sebesar 7,28 dan kelas kontrol sebesar 5,60. Data tersebut menunjukkan bahwa rata-rata kelas eksperimen lebih besar dari pada kelas kontrol. Kemudian, didapat thitung $=4,434>$ ttabel $=1,66$ sehingga dapat disimpulkan bahwa H0 yang menyatakan tidak terdapat pengaruh yang signifikan model PjBL terhadap hasil belajar kognitif level penerapan pada pembelajaran IPA ditolak. 
Pengaruh Penerapan Model Pembelajaran Project Based Learning (PJBL) terhadap

Hasil Belajar Kognitif Siswa pada Mata Pelajaran IPA di Kelas V SD Negeri 5

Kota Bengkulu

\section{c. Level Penalaran}

Sama halnya dengan level pemahaman dan penerapan, pada level pemahaman ini, peneliti menguji hipotesis mengenai pengaruh penerapan model pembelajaran PjBL terhadap kemampuan kognitif siswa level penalaran. Sebelum peneliti melakukan uji hipotesis pada masing-masing level, peneliti mengelompokkan jawaban siswa sesuai dengan masing-masing level kognitif.

Untuk menguji hipotesis tersebut, maka peneliti menggunakan data hasil Pretest dan posttest hasil belajar IPA ranah kognitif level penalaran untuk digunakan sebagai penarikan kesimpulan atas pelaksanaan penelitian ini. Adapun hasil uji hipotesis pada data pretest dan posttest sebagai berikut:

Tabel 6 Hasil Uji Hipotesis Pretest Level Penalaran

\begin{tabular}{|c|c|c|}
\hline Data & $\begin{array}{c}\text { Kelas } \\
\text { Experimen }\end{array}$ & $\begin{array}{c}\text { Kelas } \\
\text { Kontrol }\end{array}$ \\
\hline Rata-Rata & 7,94 & 7,90 \\
\hline $\mathrm{N}$ & 38 & 38 \\
\hline Df & \multicolumn{2}{|c|}{74} \\
\hline$t_{\text {hitung }}$ & \multicolumn{2}{|c|}{0,632} \\
\hline $\mathrm{tt}_{\mathrm{abel}}$ & \multicolumn{2}{|c|}{1,66} \\
\hline Kesimpulan & \multicolumn{2}{|c|}{$\begin{array}{c}\mathrm{t}_{\text {hitung }}<\mathrm{t}_{\text {tabel }} \text { maka } \mathrm{H}_{0} \\
\text { diterima }\end{array}$} \\
\hline
\end{tabular}

Berdasarkan Tabel 6 menunjukkan bahwa rata-rata nilai pada kelas eksperimen level penalaran sebesar 7,94 dan kelas kontrol sebesar 7,90. Data tersebut menunjukkan bahwa rata-rata kelas eksperimen lebih besar dari pada kelas kontrol. Kemudian, didapat thitung=0,632 < ttabel=1,66 sehingga dapat di simpulkan bahwa H0 yang menyatakan tidak terdapat pengaruh yang signifikan model pembelajaran PjBL terhadap hasil belajar kognitif level penalaran pada pembelajaran IPA diterima.

Tabel 7 Hasil Uji Hipotesis Posttest Level Penalaran

\begin{tabular}{|l|c|c|}
\hline \multicolumn{1}{|c|}{ Data } & $\begin{array}{c}\text { Kelas } \\
\text { Experimen }\end{array}$ & $\begin{array}{c}\text { Kelas } \\
\text { Kontrol }\end{array}$ \\
\hline Rata-Rata & 9,94 & 7,97 \\
\hline $\mathrm{N}$ & 38 & 38 \\
\hline $\mathrm{Df}$ & \multicolumn{2}{|c|}{74} \\
\hline $\mathrm{t}_{\text {hitung }}$ & \multicolumn{2}{|c|}{4,636} \\
\hline $\mathrm{tt}_{\text {abel }}$ & \multicolumn{2}{|c|}{1,66} \\
\hline Kesimpulan & \multicolumn{2}{|c|}{$\mathrm{t}_{\text {hitung }}>\mathrm{t}_{\text {tabel }}$ maka $\mathrm{H}_{0}$} \\
ditolak
\end{tabular}

Berdasarkan Tabel 7 menunjukkan bahwa rata-rata nilai pada kelas eksperimen level penalaran sebesar 9,94 dan kelas kontrol sebesar 7,97. Data tersebut menunjukkan bahwa rata-rata kelas eksperimen lebih besar dari pada kelas kontrol. Kemudian, didapat thitung $=4,636>$ ttabel=1,66 sehingga dapat di 
simpulkan bahwa H0 yang menyatakan tidak terdapat pengaruh yang signifikan model pembelajaran PjBL terhadap hasil belajar kognitif level penalaran pada pembelajaran IPA ditolak.

\section{Kesimpulan}

1. Kualitas projek yang dihasilkan siswa setelah penerapan model pembelajaran project based learning pada mata pelajaran IPA kelas V SDN 5 Kota Bengkulu adalah baik berdasarkan indikator tampilan secara keseluruhan, komposisi bagian-bagian dari ekosistem, projek yang dihasilkan mempunyai estetika tinggi (perpaduan warna, keserasian dalam penempatan objek, kerapian produk), dan kualitas detail tiap-tiap bagian diorama.

2. Terdapat pengaruh model pembelajaran project based learning melalui media diorama terhadap hasil belajar kognitif siswa pada materi komponen ekosistem yang terbagi dalam tiga level kognitif yaitu: pemahaman, penerapan dan penalaran.

\section{Saran}

Berdasarkan kesimpulan diatas maka peneliti memberikan saran diantaranya:

1. Untuk menghasilkan kualitas projek yang baik, diharapkan guru dituntut untuk a) Mampu memberikan pengalaman belajar, b) membantu siswa untuk meningkatkan kreatifitas, c) mengontrol siswa ketika mengerjakan projek yang berkualitas.

2. Untuk meningkatan hasil kognitif level pemahaman, penerapan, dan penalaran guru memberikan tugas-tugas yang dapat membantu siswa untuk mampu menerapkan materi yang diberikan melalui model pembelajaran Project Based Learning.

3. Penerapan model PjBL tidak hanya untuk mengukur hasil belajar ranah kognitif saja, namun pada ranah afektif seperti sikap kerja sama dalam kelompok dan psikomotor seperti keterampilan membuat projek dalam belajar kognitif.

\section{Referensi}

Farid, M., dan Pramukantoro, J. A. 2013. Pengaruh Penerapan Pembelajaran Berbasis Proyek Terhadap Hasil Belajar Siswa Pada Standar Kompetensi Menerapkan DasarDasar Teknik Digital di SMKN 2 Surabaya. Jurnal Pendidikan Teknik Elektro, 02 (02), 737-743. 
Pengaruh Penerapan Model Pembelajaran Project Based Learning (PJBL) terhadap

Hasil Belajar Kognitif Siswa pada Mata Pelajaran IPA di Kelas V SD Negeri 5

Kota Bengkulu

Hayati, M. N., K. I. Supardi, \& S. S. Miswadi. 2013. Pengembangan Pembelajaran IPA SMK dengan Model Kontekstual Berbasis Proyek untuk Meningkatkan Hasil Belajar dan Keterampilan Proses Sains Siswa. Jurnal Pendidikan IPA Indonesia, 2(1): 53-58.

Mustikaningrum. 2015. Pengaruh Model Pembelajaran Project Based Learning Berbantuan Fotonovela Terhadap Hasil Belajar Dan Sikap Sains Siswa Smp.

Nugraha, Kristin, Anugrahi. 2018. Penerapan Model Pembelajaran Project Based Learning (Pjbl) Untuk Meningkatkan Kreativitas Dan Hasil Belajar IPA Pada Siswa Kelas 5 SD.

Wahyu, R. 2017. Implementasi Model Project Based Learning (PJBL) Ditinjau dari Penerapan Kurikulum 2013. Jurnal Tecnoscienza, 1(1), 49-62. 